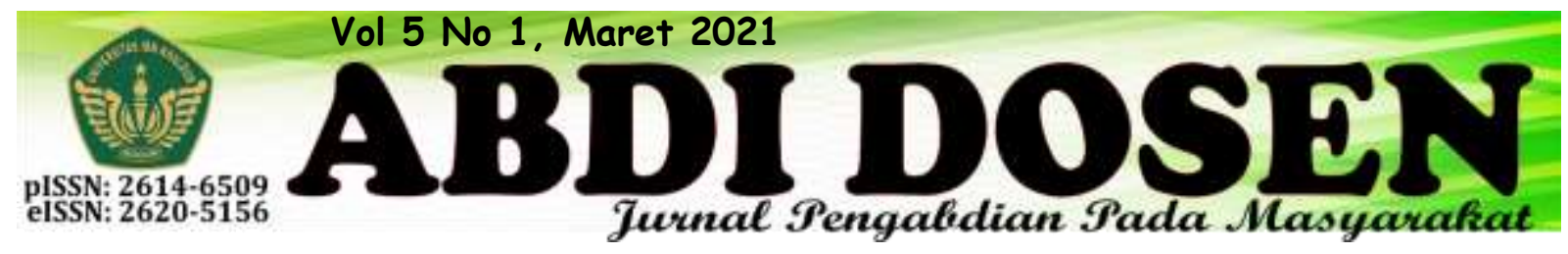

\title{
UPAYA MENINGKATKAN KESEJAHTERAAN KELUARGA DESA SADENG DENGAN MEMANFAATKAN SAMPAH YANG BERNILAI JUAL
}

\author{
Sumadi $^{1}$, Rachmatullaily Tina Kartika Rinda ${ }^{2}$, Kahfi Adriansyah $^{3}$ \\ sumadi@ft.uika-bogor.ac.id ${ }^{1}$ \\ lailyrinda@yahoo.com ${ }^{2}$ \\ kahfi@gmail.com ${ }^{3}$ \\ Fakultas Teknik dan Sains ${ }^{1}$, Fakultas Ekonomi dan Bisnis², Mahasiswa KKN Kelompok $27 \& 28$ Tahun $2019^{3}$.
}

\begin{abstract}
ABSTRAK
Permasalahan sampah adalah bagian yang tidak dapat di pisahkan dari kehidupan manusia, karena didalam kehidupan sehari-hari manusia pasti menghasilkan sampah. Berdasarkan data Asosiasi Industri Plastik Indonesia (INAPLAS) dan Badan Pusat Statistik (Kompas.com2018) bahwa produksi sampah plastik di Indonesia mencapai 64 juta ton/tahun. Berangkat dari masalah tersebut, pemerintah Kabupaten Bogor mulai memunculkan berbagai macam program sebagai solusi menangani permasalahan sampah. Salah satu Desa yang menjadi percontohan adalah Desa Sadeng di Kecamatan Leuwi Sadeng dengan program KRL (Kampung Ramah Lingkungan) ."KRL Darussalam”adalah KRL yang ada di Desa Sadeng RT.01/RW.01 dan telah berjalan selama \pm 3 tahun . Program kerjanya adalah 1) Pengelolaan Sampah \& Lubang Resapan Biopori (LRB), 2) Tata kelola lingkungan \& Penghijauan, 3) Sanitasi. Melalui program kerja tersebut, masyarakat diharapkan ikut berperan aktif dalam pengelolaan sampah untuk meningkatkan kesejahteraan kehidupan keluarganya, karena dari hasil pengamatan terdapat beberapa sampah yang memiliki nilai ekonomis jika dimanfaatkan kembali. Upaya yang dilakukan yaitu melakukan penyuluhan kepada masyarakat akan pentingnya menjaga lingkungan dalam program KRL dengan harapan masayarakat lebih antusias dalam melaksanakan program guna meningkatkan kesejahteraan kehidupan keluarga Desa Sadeng.
\end{abstract}

Kata kunci: Bank Sampah, Masalah Sampah, Manfaat Sampah

\section{PENDAHULUAN}

Berdasarkan data ScienceMag (2017), jumlah produksi sampah plastik global sejak tahun 1950 hingga 2015 cenderung selalu menunjukkan peningkatan. Pada tahun 1950, produksi sampah dunia ada di angka 2 juta Ton pertahun. Sementara 65 tahun setelah itu, pada taun 2015 produksi sampah sudah ada di angka 381 juta ton pertahun (Kompas.com, 2018). Sedangkan untuk di
Indonesia sendiri, berdasarkan data yang diperoleh dari Asosiasi Industri Plastik Indonesia (INAPLAS) dan Badan Pusat Statistik (BPS), sampah plastik di indonesia mencapai 64 juta ton/tahun dimana sebanyak 3,2 juta ton merupakan sampah plastik yang dibuang kelaut. (Kompas.com, 2018)

Sampah merupakan salah satu permasalahan yang patut untuk 
diperhatikan. Sampah adalah bagian yang tidak dapat dipisahkan dari kehidupan manusia, karena pada dasarnya manusia pasti menghasilkan sampah. Sampah merupakan suatu buangan (output) yang dihasilkan dari setiap aktivitas manusia. Setiap aktivitas manusia, baik pribadi maupun kelompok, dirumah, kantor, pasar, sekolah, maupun dimana saja dapat menghasilkan sampah, baik sampah organik maupun anorganik. Oleh karena itu, dapat disimpulkan bahwa volume peningkatan sampah sebanding dengan meningkatnya tingkat konsumsi manusia.

Didalam upaya untuk mencegah terjadinya pencemaran lingkungan yang diakibatkan oleh sampah, pemerintah mengeluarkan undang-undang tentang pemanfaatan atau pengelolaan sampah yaitu dalam Undnag-Undang RI Tahun 2008 Nomor 18 tentang pengelolaan sampah bertujuan agar menjadikan sampah sebagai sumber daya. Berdasarkan tujuan inilah maka pemerintah berupaya untuk mengubah pola pikir masyarakat yang masih menggunakan sistem kumpulangkut- buang sebagai solusi penanganan sampah, Kemudian diarahkan pada kegiatan pengurangan dan penanganan sampah dengan kegiatan 3R yaitu Reuse, Reduce, dan Recycle. Dengan melakukan sosialisasi kepada msyarakat, membentuk organisasi-organisasi berbasis peduli lingkungan, salah satu contohnya adalah Kampung Ramah Lingkungan yang mana mempunyai program Bank Sampah.

Kampung Ramah Lingkungan adalah suatu lokasi yang masyarakatnya melakukan upaya atau tindakan nyata dalam perlindungan dan pengelolaan lingkungan hidup secara terstruktur dan berkesinambungan. Sedangkan tujuannya adalah untuk mendorong pemerintah daerah, dunia usaha dan masyarakat setempat untuk memahami permasalahan lingkungan dan dampaknya, serta melakukan tindakan proaktif yang berkontribusi kepada upaya perlindungan dan pengelolaan lingkungan hidup.

Bank sampah merupakan tempat pengelolaan sampah yang menerapkan sistem 3R dan penyetoran sejumlah sampah kebadan yang telah dibentuk oleh masyarakat setempat. Bank sampah juga memiliki manfaat penting bagi masyarakat, baik dalam bidang ekonomi, sosial, kesehatan maupun bidang spriritual. Dalam bidang ekonomi yaitu masyarakat dapat memperoleh uang dari sampah yang ditabungkan pada bank smapah, yang dapat diambil dalam kurun waktu tertentu sesuai dengan kesepakatan yang telah ditetapkan bersama sebelumnya. Dan masyarakat dapat mendapatkan manfaat ekonomi melalui kegiatan daur ulang sampah menjadi kerajinan yang dapat dijual, seperti tas, tamplak meja, hiasan, aksesoris, dan lain-lain.

Sedangkan manfaat sosial yang dapat diberikan oleh kegiatan Bank Sampah kepada masyarakat yaitu melalui kegiatan sosialisasi dari organisasi Kampung Ramah Lingkungan mengenai program Bank Sampah, masyarakat diajarkan untuk memilah sampah antara sampah organik dan anorganik (Suwerda, 2012). Lalu masyarakat juga diarahkan untuk menjadi pribadi yang kreatif dalam mengelola sampah dengan mengubahnya menjadi barang yang memiliki nilai material.

Dan manfaat dalam bidang kesehatan yang bisa didapatkan masyarakat dari program Bank Sampah yaitu sudah bisa dipastikan dengan adanya program Bank sampah masyarakat dapat mencegah bencana yang ditimbulkan oleh sampah, baik itu untuk dirinya sendiri ataupun bagi lingkungan. Sehingga akan didapatkanlah 
lingkungan yang bersih, sehat, indah dan nyaman.

\section{Rumusan Masalah}

Berdasarkan latar belakang masalah yang telah diuraikan, maka diperoleh rumusan masalah kegiatan yaitu Bagaimana meningkatkan kualitas hidup masyarakat Desa Sadeng melalui program Kampung Ramah Lingkungan dan program kegiatan lainnya.

\section{Tujuan}

Sesuai dengan rumusan masalah yang telah ada, maka tujuan yang akan dicapai pada kegiatan ini yaitu untuk mengetahui bagaimana meningkatkan kualitas hidup masyarakat Desa Sadeng melalui program Kampung Ramah Lingkungan dan program kegiatan lainnya.

\section{METODOLOGI}

\section{Tahap pelaksanaan}

Tahap pelaksanaan untuk kegiatan ini sebagaimana terlihat pada bagan berikut ini:

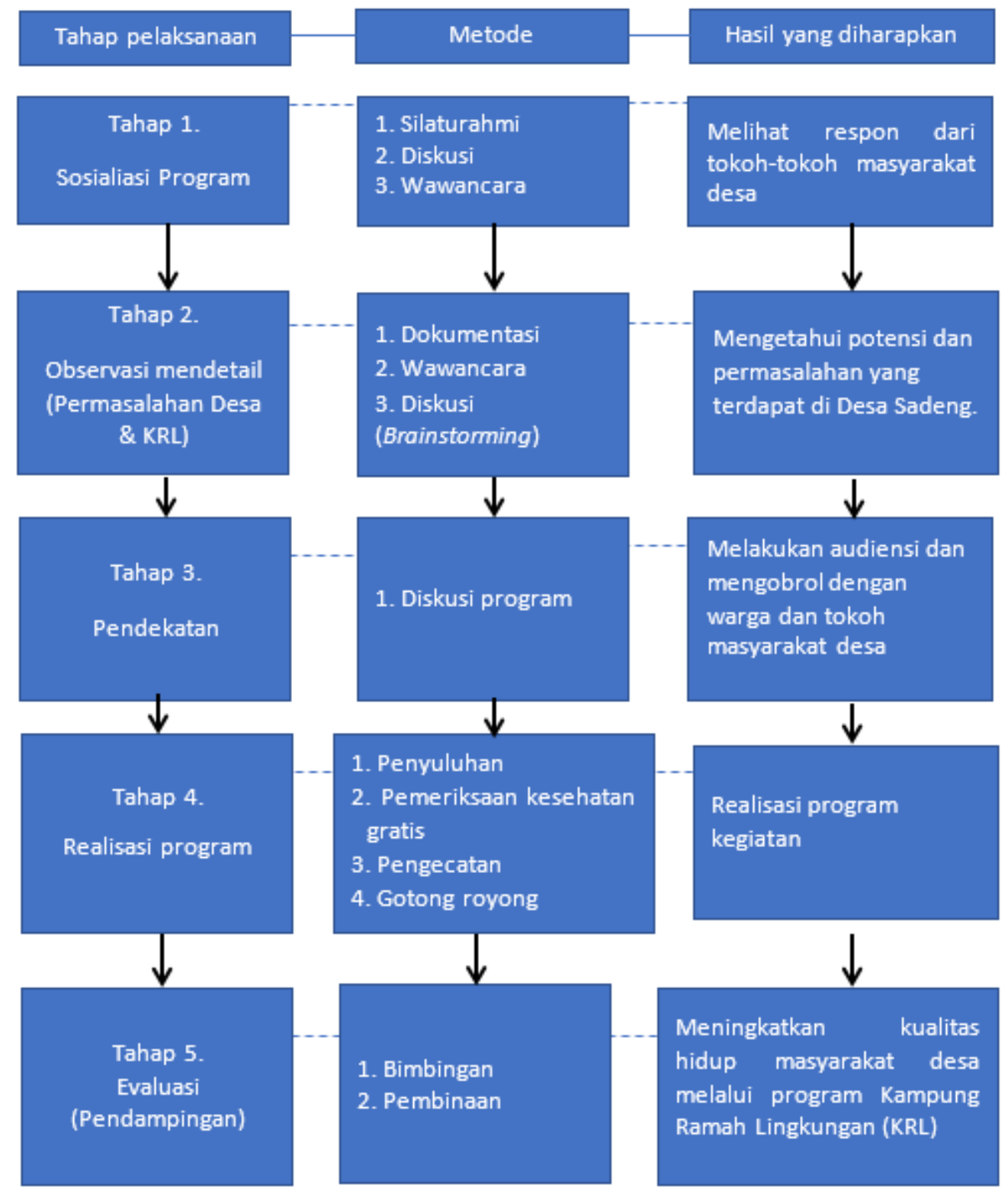


Jadwal pelaksanaan kegiatan

\begin{tabular}{|c|c|c|c|c|c|}
\hline \multirow[b]{2}{*}{ No } & \multirow{2}{*}{ Kegiatan } & \multicolumn{4}{|c|}{ Minggu } \\
\hline & & 1 & 2 & 3 & 4 \\
\hline 1 & Penyusunan Rencana Kegiatan & & & & \\
\hline 2 & Penyusunan Struktur KKN & & & & \\
\hline 3 & Mengajar di madrasah Diniyah & & & & \\
\hline 4 & Bimbel bahasa Inggris & & & & \\
\hline 5 & Minggu bersih & & & & \\
\hline 6 & Sosialisasi Bank Sampah & & & & \\
\hline 7 & $\begin{array}{l}\text { Mengajar di Madrasah Ibtidaiyah Taman } \\
\text { Pendidikan Islam(MITPI) }\end{array}$ & & & & \\
\hline 8 & Revitalisasi perpustakaan desa & & & & \\
\hline 9 & Pengecetan Paving Blok & & & & \\
\hline 10 & Panitia 17 Agustusan & & & & \\
\hline 11 & Pengajian Remaja & & & & \\
\hline 12 & Penyuluhan "Rencana finansial keluarga" & & & & \\
\hline 13 & Penyuluhan hipertensi dan cek kesehatan & & & & \\
\hline 14 & Penyuluhan "cuci tangan bersih" & & & & \\
\hline 15 & $\begin{array}{l}\text { Seminar hukum "kesadaran generasi milenial } \\
\text { akan bahayanya kenakalan remaja" }\end{array}$ & & & & \\
\hline 16 & Penyuluhan "Ayo gemar menabung" & & & & \\
\hline 17 & Pembuatan alat pembakar sampah & & & & \\
\hline 18 & Penutupan & & & & \\
\hline 19 & Pembuatan laporan KKN & & & & \\
\hline
\end{tabular}

\section{Metode Pendekatan}

Pendekatan adalah sudut pandang seseorang dalam memandang suatu hal (Dici, 2016). Adapun bentuk-bentuk pendekatan sosial yang dilakukan kepada masyarakat didalam pelaksanaan kegiatan ini adalah:

1. Pendekatan religius

Yaitu pendekatan yang menggunakan nilai-nilai agama sebagai basis kegiatan. Pendekatan ini dipengaruhi oleh faktor keimanan, pengalaman keagamaan, rasa tanggungjawab dan pengetahuan. Bentuk pendekatan ini dilakukan di Majlis dan Masjid pada saat kajian agama dan mengajar mengaji.

2. Pendekatan kekerabatan

Pendekatan yang dilakukan senantiasa dikaitkan dalam rangka membangun kekerabatan antar masyarakat. Bentuk pendekatan ini dilakukan lewat diskusi dan mengobrol santai dengan masyarakat.

3. Pendekatan berdasarkan karakter masyarakat

Pendekatan yang dilakukan disesuaikan dengan karakter masyarakat/warga dalam suatu daerah. Bentuk pendekatan ini dilakukan melalui rapat dan kegiatan-kegiatan yang dilaksanakan saat program KRL dan Karang Taruna berlangsung.

4. Pendekatan berbasis IT (Ilmu Teknologi)

Artinya melalui pemanfaatan ilmu teknologi yaitu dengan cara memberikan arahan untuk menjangkau jaringan yang luas, masyarakat mampu mengikuti perkembangan di era globalisasi. Pendekatan ini ditujukan kepada generasi muda desa dan dengan menggunakan teknologi sebagai medianya. 


\section{REALISASI PROGRAM}

Kuliah Kerja Nyata Tematik Terintegrasi periode 06 Agustus sampai dengan 06 September 2019 di Desa Sadeng Kecamatan Leuwisadeng Kabupaten Bogor dimulai pada tanggal 06 Agustus sampai dengan 05 September 2019 yang terdiri dari 29 mahasiswa dari berbagai fakultas yang terdiri dari Fakultas Agama Islam, Fakultas Keguruan Ilmu Pendidikan, Fakultas Ekonomi, Fakultas Teknik, Fakultas Hukum, Fakultas Kesehatan dan juga Fakultas Teknik. Tujuan dari KKN sendiri adalah agar mahasiswa dapat mengabdi dan belajar dari masyarakat mengenai kehidupan bermasyarakat yang sesungguhnya, khususnya dalam hal ini pengabdian kepada masyarakat mengenai peran program Kampung Ramah Lingkungan (KRL).

Sebelum

kegiatan

$\mathrm{KKN}$ dilaksanakan, mahasiswa menerima pembekalan terlebih dahulu mengenai pelaksanaan kegiatan KKN yang akan dilaksanakan oleh Dosen Pendamping Lapangan (DPL) pada tanggal 01 Agustus 2019. Pembekalan dilakukan dengan tujuan agar mahasiswa peserta KKN dapat mengerti serta memahami maksud dan tujuan dilaksanakannya $\mathrm{KKN}$ dan juga agar mahasiswa mengetahui bagaimana mekanisme pelaksanaan KKN itu sendiri. Setelah pembekalan yang diberikan oleh DPL, pada tanggal 4 Agustus 2019 mahasiswa dengan didampingi DPL melakukan survey lokasi KKN untuk melihat langsung kondisi keadaan di daerah Desa Sadeng Kecamatan Leuwisadeng.

Desa Sadeng terletak di wilayah pembangunan Bogor Barat dan merupakan salah satu dari delapan desa yang berada di Kecamatan Leuwisadeng hasil pemekaran dari Kecamatan Leuwiliang pada tahun 2005. Total luas wilayah desa Sadeng adalah $463 \mathrm{Ha}$, terdiri dari 3 Dusun yang terdiri dari 6 Rukun Warga (RW) dan 30 Rukun Tetangga (RT) dengan pembagian zonasi pemukiman/perkampungan, sawah, perkebunan dan Perbukitan. Potensi unggulan di Desa Sadeng yang masih tetap eksis hingga saat ini di bidang Pertanian yaitu adanya para petani manggis, durian, dan pala Untuk potensi lainnya yang ada peningkatan dan signifikan di bidang kewirausahaan dan palawija. Secara geografis batas wilayah desa sadeng sebagai berikut:

\begin{tabular}{|r|l|c|c|}
\hline \multicolumn{1}{|c|}{ No } & \multicolumn{1}{|c|}{ Batas } & Desa/ kelurahan & Kecamatan \\
\hline 1. & Utara & Banyuresmi & Cigudeg \\
\hline 2. & Selatan & Babakan Sadeng & Leuwisadeng \\
\hline 3. & Barat & Kalong II & Luewisadeng \\
\hline 4. & Timur & Sibanteng & Leuwisadeng \\
\hline
\end{tabular}

Adapun detail dari jumlah penduduk Desa Sadeng pada tahun 2017-2018 dapat dilihat dari Tabel sebagai berikut:

\begin{tabular}{|c|c|c|c|c|}
\hline \multirow{2}{*}{ No. } & \multirow{2}{*}{ RW \& Alamat } & \multicolumn{2}{|c|}{ Jumlah Penduduk } & \multirow{2}{*}{ Jumlah } \\
\cline { 3 - 4 } & \multicolumn{2}{|}{ Rumah } \\
\hline 1 & $001-$ Kp. Sadeng & 2,593 & 705 & 355 \\
\hline 2 & $002-$ Kp. Sadeng & 2,700 & 690 & 560 \\
\hline
\end{tabular}




\begin{tabular}{|c|c|c|c|c|}
\hline 3 & $003-$ Kp. Paku & 1,461 & 393 & 297 \\
\hline 4 & $004-$ Kp. Paku & 2,188 & 565 & 405 \\
\hline 5 & $005-$ Kp. Cikadu & 1.290 & 328 & 247 \\
\hline 6 & $006-$ Kp. Gn.Seureuh & 559 & 109 & 90 \\
\hline \multicolumn{2}{|c|}{ Jumlah } & $\mathbf{1 0 . 8 0 5}$ & $\mathbf{2 . 7 9 0}$ & $\mathbf{1 . 9 5 4}$ \\
\hline
\end{tabular}

Setelah melakukan survey lokasi, pada tanggal 05 Agustus 2019 mahasiswa melakukan pertemuan dengan semua anggota kelompok untuk merencanakan program kegiatan yang akan direalisasikan kepada masyarakat. Pada tanggal 06 Agustus 2019 seluruh mahasiswa peserta KKN menghadiri acara pembekalan dan pelepasan kegiatan KKN oleh rektor Universitas Ibn Khaldun Bogor beserta Bupati Bogor di masjid Raya Al-Hijri 2. Dan realisasi program dimulai pada tanggal 07 Agustus 2019 sampai dengan selesai dengan berpedoman kepada timeline yang telah dibuat dan dengan menyesuaikan dengan situasi dan kondisi masyarakat pada saat itu.

Setelah menggali permasalahanpermasalahan yang terdapat didalam program Kampung Ramah Lingkungan (KRL) melalui studi dokumen, observasi, dan wawancara, diperoleh sejumlah kendala yang dihadapi oleh KRL dalam melaksanan kegiatan secara besar dan menyeluruh adalah kurangnya minat \& pemahaman masyarakat atas manfaat dari program tersebut sehingga menyebabkan tersendatnya pelaksanaan program. Berdasarkan hal tersebut, disusunlah program-program yang mampu menjadi solusi atas kendala didalam pelaksanaan program Kampung Ramah Lingkungan (KRL) dan sejumlah kegiatan lain sebagai penunjang program Kampung Ramah Lingkungan (KRL) yang berasal dari ideide pemikiran mahasiswa dalam kegiatan
KKN Terintegrasi. Berikut ini uraian program-program kegiatan kelompok KKN Desa Sadeng, Kecamatan Leuwisadeng, Kabupaten Bogor.

Program kegiatan berjalan mulai dari

07 Agustus 2019 hingga 05 September 2019. Dengan 7 Divisi yaitu :

\section{Divisi Ekonomi}

2. Divisi Kesehatan

3. Divisi Hukum

4. Divisi Pendidikan

5. Divisi Keagamaan

6. Divisi Teknik

7. Divisi Umum

Adapun uraian mengenai keterlaksanaan program yaitu sebagai berikut :

\section{Divisi Ekonomi}

1) Program "Ayo gemar menabung"

Kuliah kerja nyata (KKN) terintegrasi 2019 Desa Sadeng, Kec. Leuwisadeng, Kab. Bogor mengadakan kegiatan yang sangat berpengaruh bagi masyarakat Desa Sadeng, terutama pada anak anak usia dini karena kegiatan tersebut mengenai penyuluhan dengan tema "ayo gemar menabung". Dengan diadakannya penyuluhan anak-anak tersebut, anak-anak diajarkan tentang prilaku gemar menabung dan tidak boros serta tentang pentingnya kebiasaan menabung sejak dini sebagaimana disampaikan didalam Al-Quran surat AlIsra ayat 27 tentang larangan berperilaku boros. Hal tersebut bertujuan agar timbul kesadaran didalam generasi muda untuk 
dapat menyisihkan sebagian dari uang mereka untuk ditabungkan.

Berangkat dari tema kelompok KKN Desa Sadeng yang berhubungan dengan Kampung Ramah Lingkungan, acara ini dikaitkan dengan mengajarkan anak-anak akan pentingnya menjaga lingkungan. Salah satu cara yang dilakukan yaitu dengan mendaur ulang sampah botol bekas dan sedotan plastik sebagai media bagi anak-anak untuk menuangkan kreatifitas anak-anak dengan cara menghiasnya dan menjadikannya sebuah celengan. Program ini disusun untuk membangun serta meningkatkan kreativitas anak-anak Rt.01 kampung Sadeng dalam memanfaatkan barang-barang bekas yang ada dilingkungan sekitar menjadi barang yang bermanfaat. Pelaksanaan kegiatan ini bekerjasama dengan Pondok Pesantren Kuntum sebagai tempat terselenggaranya kegiatan tersebut.

Alasan dan Tujuan

a) Mengajarkan generasi muda Desa Sadeng pentingnya dan keuntungankeuntungan menabung sejak dini.

b) Meningkatkan antusiasme generasi muda Desa Sadeng terhadap kegiatan menabung.

\section{Penyuluhan Perencanaan Financial Keluarga}

Mahasiswa Kuliah kerja nyata (KKN) terintegrasi 2019 desa sadeng kecamatan leuwisadeng kabupaten Bogor yang berlokasi di majlis ta'lim miftahul aulad RT 03/01 mengadakan suatu kegiatan dalam bidang ekonomi yaitu penyuluhan mengenai perencanaan financial keluarga.

Program tersebut dilaksanakan berdasarkan pertimbangan untuk meningkatkan pemahaman untuk mengatasi permasalah keuangan yang selama ini sering dialami oleh keluarga diantaranya perencanaan yang tidak matang, penggunaan alokasi dana yang kurang efektif, lilitan hutang dari pinjaman bank keliling dan lain-lain.

Alasan dan Tujuan

a) Meningkatkan kesadaran masyarakat akan pentingnya peranan kaum ibu untuk belajar mengatur ekonomi keluarga.

b) Mengantisipasi terjadinya masalah keuangan keluarga,seperti sampai terbelit hutang dengan melakukan perencanaan keuangan resiko yang mungkin timbul dapat di antisipasi.

c) Masyarakat desa Sadeng dapat mengelola pemasukan dan pengeluaran keuangan secara efektif.

\section{Sosialisasi Bank Sampah}

Bank sampah merupakan suatu kegiatan yang direalisasikan dari salah satu program Kampung Ramah Lingkungan yaitu Pengelolaan Sampah \& Lubang Resapan Biopori (LRB). Sosialisasi ini dilakukan agar menumbuhkan minat serta mengajak masyarakat untuk ikut serta bergabung menjadi peserta bank sampah.

Sampah dipilah menjadi beberapa kategori, seperti : gelas-gelas akua, plastik, kardus, alumunium, dll. setiap dua minggu sekali diadakan penimbangan sampah, yang mana hasil penimbangan tersebut menjadi tabungan masyarakat yang dapat diambil dalam kurun waktu tertentu.

Alasan dan Tujuan

a) Untuk menumbuhkan minat masyarakat hidup besih dan sehat

\section{Divisi Kesehatan}

\section{Cek kesehatan gratis dan penyuluhan hipertensi}

Berdasarkan survei yg dilakukan menyatakan bahwa masalah kesehatan yang ada di desa sadeng adalah Penyakit Tidak Menular dan mayoritas penyakitnya adalah Hipertensi, sehingga masyarakat 
butuh edukasi atau pengetahuan tentang hipertensi bagaimana cara pengertian, penyebab dan pencegahan dari hipertensi. Oleh karena itu pada tanggal 24 Agustus 2019 peserta KKN Desa Sadeng Kecamatan Leuwisadeng Kabupaten Bogor, melakukan kegiatan Penyuluhan dan Cek Kesehatan Gratis yang bekerjasama dengan ISMAKES (ikatan Mahasiswa Kesehatan) Bogor.

Penyuluhan hipertensi ini sendiri berisikan tentang penjelasan hipertensi juga menjelaskan tentang bagaimana penyebab dan pencegahan hipertensi. Setelah melakukan penyuluhan kegiatan ini dilanjutkan dengan cek kesehatan gratis yang dilakukan oleh ISMAKES Bogor meliputi: cek tekanan darah, gula darah, kolesterol dan asam urat. Acara ini di di hadiri oleh masyarakat desa sadeng RW. 01 .

Alasan dan Tujuan

a) Menigkatkan pemahaman masyarakat tentang penyakit tidak menular \& hipertensi.

b) Meningkatkan kualitas hidup masyarakat dalam aspek kesehatan.

c) Timbal balik mahasiswa kepada masyarakat Desa Sadeng dalam aspek kesehatan.

\section{Penyuluhan Pola Hidup Bersih dan} Sehat "Cuci Tangan Pakai Sabun"

KKN UIKA desa sadeng mengadakan penyuluhan tentang pola hidup bersih dan sehat dengan Cuci Tangan pada tanggal 22 Agustus 2019 di MI. Al-Khoeriyah. Perilaku hidup bersih dan sehat (PHBS) adalah upaya untuk memberikan pengalaman belajar atau menciptakan suatu kondisi bagi perorangan, keluarga, kelompok dan masyarakat, dengan membuka jalan komunikasi, memberikan informasi dan melakukan edukasi, untuk meningkatkan pengetahuan, sikap dan perilaku, melalui pendekatan pimpinan (advokasi), bina suasana (social support) dan pemberdayaan masyarakat (empowerment) sebagai suatu upaya untuk membantu masyarakat mengenali dan mengatasi masalahnya sendiri, dalam tatanan masing-masing, agar dapat menerapkan cara-cara hidup sehat, dalam rangka menjaga, memelihara dan meningkatkan kesehatan.

Penyuluhan ini dilakukan untuk memberikan Pengetahuan kepada siswa mengenai pola hidup bersih dan sehat dengan cuci tangan yang baik dan benar, penyuluhan ini juga mengajarkan bagaimana cara mencuci tangan yang baik dengan menggunakan 6 langkah cuci tangan yang benar, dan siswa mampu mengaplikasikannya dalam kehidupan sehari-hari Dapat mengubah kebiasaan buruk siswa mengenai cuci tangan.

Alasan dan Tujuan

a) Memberikan pengetahuan4 kepada siswa/siswi Desa Sadeng mengenai pola hidup bersih dan sehat dengan cuci tangan yang baik dan benar.

b) Meningkatkan antusiasme siswa/siswi didalam mencuci tangan dengan cara yang baik dengan menggunakan 6 langkah cuci tangan.

c) Timbal balik mahasiswa kepada masyarakat Desa Sadeng dalam aspek kesehatan.

\section{Divisi Hukum}

Seminar Hukum "Kesadaran Hukum

Generasi Milenial akan Bahayanya Kenakalan Remaja"

peserta KKN dari fakultas hukum sekecamatan Leuwisadeng mengadakan suatu seminar yang diperuntukkan untuk siswa-siswi sekolah Menengah Atas (SMA) dengan diisi oleh pemateri Bapak Dr. Ibrahim Fajri SH, M.E.I dan LBH UIKA Bogor. Kegiatan ini dilatarbelakangi 
oleh maraknya peristiwa yang terjadi dikalangan pelajar saat ini. Yang mana remaja merupakan aset masa depan dari suatu bangsa. Di samping hal-hal yang menggembirakan dengan kegiatan positif dan prestasi yang diraih remaja-remaja pada waktu akhir-akhir ini serta pembinaan yang dilakukan oleh organisasi-organisasi pelajar dan mahasiswa, kita juga melihat arus kemerosotan moral yang semakin melanda di kalangan sebagian pemudapemuda kita, yang sering dikelanal dengan sebutan kenakalan remaja. Dalam pemberitaan, media cetak dan media televisi sering kali kita menemui berita tentang perkelahian pelajar, penyebaran narkotika, minuman keras, penjambretan dan pencurian lainnya yang dilakukan anak-anak berusia belasan tahun serta meningkatnya kasus-kasus kehamilan dikalangan remaja putri dan lain sebagainya.

Hal tersebut merupakan suatu masalah dari kenakalan remaja yang dihadapi oleh masyarakat yang kini semakin marak terjadi, Oleh karena itu masalah kenakalan remaja seharusnya mendapatkan perhatian yang serius dan terfokus untuk mengarahkan remaja ke arah yang lebih positif, yang tujuannya untuk terciptanya suatu sistem dalam menanggulangi kenakalan di kalangan remaja.

Alasan dan Tujuan

a) Semakin meningkatnya kemerosotan moral yang melanda generasi muda, yang sering dikelanal dengan sebutan kenakalan remaja.

b) Memberikan pemahaman generasi muda (Jenjang SMA) terhadap permasalahan merosotnya moral dan konsekwensi didalam kehidupan bermasyarakat. c) Sumbangsih dari mahasiswa kepada generasi muda diwilayah kecamatan Leuwisadeng dalam aspek hokum.

\section{Divisi Pendidikan}

\section{Program "Bimbel Bahasa Inggris"}

Program mengajar mengajar bimbel bahasa Inggris di Desa Sadeng dilaksanakan selama jangka waktu \pm satu bulan secara fleksible setelah ba'da sholat Isya. Kegiatan mengajar bimbel kepada anak-anak ini dapat terlaksana lewat bantuan dari kepala RT 03/ RW 01 dan segenap masyarakat desa yang telah menyebarluaskan informasi tentang program ini kepada anak-anak dilingkungan Desa. Mahasiswa/i dari sejumlah fakultas lainnya diikutsertakan untuk mengajar pada program bimbel ini. Adapun mahasiswa UIKA yang mengajar pada program bimbel ini terdiri dari mahasiswa dari Fakultas Ilmu Pendidikan (FKIP), Fakultas Ekonomi \& Bisnis (FEB) dan Fakultas Ilmu Kesehatan (FIKES). Materi yang diajarkan biasanya disesuaikan dengan PR yang dikerjakan oleh anak-anak

Alasan dan Tujuan

a) Sebagai aplikasi dari teknik dan metode pembelajaran yang dipelajari di Universitas.

b) Sebagai upaya didalam meningkatkan minat belajar siswa.

c) Sebagai timbal balik dari mahasiswa terhadap masyarakat di Desa Sadeng dalam bidang pendidikan.

\section{Mengajar di MI. Taman Pendidikan Islam Desa Sadeng}

Program mengajar di Madrasah Ibtidaiyah Taman Pendidikan Islam, Desa Sadeng adalah kegiatan yang menjadi program utama dan andalan dalam aspek pendidikan program KKN di Desa Sadeng. Pelaksanaan program kegiatan tersebut berdurasi selama \pm 2 Minggu (12 hari). 
Kegiatan mengajar di Desa Sadeng dapat terlaksana lewat izin dari kepala sekolah MI TPI dan mahasiwa UIKA. 13 Mahasiswa diikutsertakan dari berbagai fakultas untuk mengajar di MI TPI kelas 3 sampai 6. Adapun mahasiswa UIKA yang mengajar terdiri dari mahasiswa dari Fakultas Ilmu Pendidikan (FKIP), Fakultas Agama Islam (FAI), Fakultas Ekonomi \& Bisnis (FEB) dan Fakultas Ilmu Kesehatan (FIKES) yang mengajar mata pelajaran Bahasa Arab, Bahasa Inggris, Matematika, Akidah \& Akhlak dan guru kelas (tematik). Alasan dan Tujuan

a) Sebagai aplikasi dari teknik dan metode pembelajaran yang dipelajari di Universitas.

b) Sebagai upaya didalam meningkatkan minat belajar siswa.

c) Sebagai timbal balik dari mahasiswa terhadap masyarakat di Desa Sadeng dalam bidang pendidikan.

\section{Revitalisasi Perpustakaan Desa}

Kurangnya minat membaca generasi muda desa Sadeng yang disebabkan oleh beberapa faktor salah satunya adalah kurangnya fasilitas yang memadai di perpustakaan desa. Berangkat dari permasalahan tersebut, mahasiswa berupaya merapihkan fasilitas desa tersebut dengan mengembangkan kualitas perpustakaan desa yang belum digarap secara optimal. Adapun bentuk kegiatan yang dilakukan mahasiswa antara lain adalah dengan merapihkan dan membuat rak buku untuk perpustakaan desa. Hal tersebut dilakukan karena mempertimbangkan kurangnya ketersediaan rak buku di perpustakaan yang menyebabkan tercecernya buku-buku bacaan yang terdapat di perpustakaan.

Selanjutnya, mahasiswa mendonasikan beberapa jenis buku dan komik untuk perpustakaan desa Sadeng dengan tujuan untuk meningkatkan variasi bahan bacaan di perpustakaan. Hal tersebut dilakukan dengan pertimbangan untuk memberikan berbagai macam pilihan buku bacaan kepada pengunjung perpustakaan sehingga minat baca mereka semakin bertambah.

Alasan dan tujuan

a) Upaya didalam meningkatkan minat membaca generasi muda Desa Sadeng.

b) Timbal balik dari mahasiswa terhadap masyarakat di Desa Sadeng dalam bidang pendidikan.

\section{Divisi Keagamaan}

\section{Mengajar di Madrasah Diniyah}

Mahasiswa mengajar di 3 Madrasah Diniyah yang berbeda yang terletak di RW 01, 02 dan 06. Didalam program mengajar MD Nurul Mubin, kurikulum yang digunakan adalah kurikulum klasik meliputi al-Qur'an dan agama, membaca, menulis, sya'ir, dan sebagian prinsipprinsip pokok agama dan ditambah juga dengan nahwu, cerita dan berenang. Untuk pelajar putra-putri tingkat lanjut, pentingnya pelajaran khitabah (pidato), ilmu sejarah, cerita perang, cara-cara pergaulan, di samping ilmu-ilmu pokok seperti al-Qur'an, sya'ir dan figh. Majelis Nurul Mubin pada umumnya untuk tingkat klasik diajarkan al-Qur'an, dan dimasukkan materi lain seperti sejarah islam, hukum islam, dan berhitung sehingga kemampuan anak-anak dalam tulis menulis dan khat serta membaca Al-Qur'an yang baik dan benar yang sesuai dengan hukum tajdwidnya sangat menonjol.

Program pengajaran di Majelis Miftahul Aulad, mengingat usia anak-anak yang mengajar masih diusia 6-12 tahun, masih belajar mengenai pengenalan huruf bahasa arab dan hokum bacaan dengan menggunakan buku Iqro'. Selain itu,anakanak juga diajarkan membaca surat-surat 
pendek, bacaan shalat, do'a sehari-hari dan nyanyian-nyanyian islami yang memiliki nilai islami. di Madrasah Diniyah Tarbiyatul Aulad yang terletak di RT 01/ RW 06 bersifat informal. Kegiatan belajar mirip seperti disekolah pada umumnya. Adapun materi peljaran di madrasah ini lebih memfokuskan kepada pembelajaran agama seperti Aqidah Akhlak, Fiqih, Bahasa Arab, dan Al-Qur'an Hadis dengan disertai buku pegangan guru seperti layaknya di sekolah. Pembelajaran di Madrasah Diniyah dilakukan dari hari senin sampai jum'at, mulai pukul 16.00 sampai 17.00 WIB. Dalam 1 madrasah terdapat 5 kelas, mulai dari kelas 1 sampai kelas 5, Murid di madrasah diniyah didominasi oleh anak-anak dalam rentang umur 6-13 Tahun. Setiap kelas mendapatkan pembelajaran yang berbeda sesuai dengan jenjangnya masing-masing.

Alasan dan Tujuan

a) Mencetak generasi penerus bangsa yang memiliki keimanan dan ketakwaan kepada Allah SWT.

b) Mengaplikasikan pengetahuan dan teori pengajaran yang diperoleh dibangku kuliah.

\section{Pengajian Remaja}

Pengajian agama merupakan salah satu bentuk kegiatan dakwah atau tabligh, karena di dalam pengajian itu sendiri tidak lepas dari usaha penyampaian ajaranajaran Islam dalam rangka mengajak atau membina umat manusia untuk senantiasa berada di jalan Islam, sehingga tercapai kedamaian dan kebahagiaan di dunia dan di akhirat.

Pengajian hanya dilaksanakan oleh IKREMA (Ikatan Remaja Masjid) Nurul Muhibbin di masjid-masjid sekitar tempat tinggal, bahkan peserta atau audiens yang mengikuti pengajian tidak hanya anak anak remaja tapi juga para karyawan atau pekerja seperti para peserta pengajian yang berumur 30 tahun keatas. Dakwah Islam atau pengajian di lingkungan remaja merupakan upaya untuk memenuhi kebutuhan rohani para pemuda penerus bangsa, sehingga ada keseimbangan antara kebutuhan rohani dan kebutuhan jasmani para remaja.

Pengajian rutinan Masjid Nurul Muhibbin Desa Sadeng dilaksanakan setiap hari Jum'at Malam setelah salat Isya berjamaah. Waktu pengajiannya berdurasi selama satu sampai dengan 2 jam. Metode yang digunakan dalam pengajian tersebut adalah ceramah.

Di pertemuan jum'at pertama yakni pada tanggal 9 Agustus 2019, kami mengkaji tentang Fiqih Ibadah, lalu dipertemuan kedua yakni pada hari jum'at tanggal 16 Agustus 2019, kami mengkaji tentang Tauhid, selanjutnya dipertemuan ketiga yakni pada tanggal 23 Agustus 2019, kami mengkaji tentang Al-Qur'an, dan dipertemuan terakhir yakni pertemuan yang keempat tepatnya pada tanggal 30 Agustus 2019, kami mengkaji Hadits. Setiap pertemuan kegiatan berlangsung secara lancar dan khitmat sehingga apa yang disampaikan dan diajarkan kepada kami menjadi sesuatu yang bermanfaat selagi menjalankan kegiatan program KKN.

\section{Alasan dan Tujuan}

Membina dan mengembangkan hubungan yang santun dan sesuai atau serasi antara manusia dengan Allah, antara manusia dengan manusia lainnya, antara manusia dengan tempat tinggal sekitarnya atau lingkungan, dalam rangka meningkatkan ketaqwaan mereka kepada Allah SWT. 


\section{Divisi Teknik}

\section{Pengecatan Paving Blok di gang/Jalan masuk kampung sadeng}

Untuk merealisasikan salah satu program KRL Darussalam, yaitu program Tata kelola lingkungan \& Penghijauan, program ini mengupayakan masyarakat untuk memaksimalkan pemanfaatan lahan baik lahan umum maupun lahan pekarangan rumah. Upaya ini juga bertujuan untuk menciptakan Kawasan Rumah Pangan Lestari (KRPL). Lingkup kegiatannya antara lain (1) Pengecatan jalan lingkungan tiap RT, (2) Pembuatan graffiti, (3) Pembuatan LRB di tiap RT, (4) Memanfaatkan halaman sebagai tambulapot dan (5) Membuat kebun KRL.

Pada tanggal 13 Agustus 2019 KKN Desa Sadeng melakukan Pengecatan paving blok di jalan masuk atau gang ke kampung sadeng. Kegiatan ini pun bertujuan guna memperindah jalanan kampung sadeng dan juga membangkitkan rasa kesadaran masyarakat untuk perduli terhadap keindahan lingkungan.

Alasan dan Tujuan

a) Untuk meningkatkan tata kelola lingkungan dilingkungan Desa Sadeng.

b) Dekorasi lingkungan Desa Sadeng untuk memperingati hari kemerdekaan Indonesia.

c) Timbal balik mahasiswa kepada masyarakat Desa Sadeng dalam aspek tata kelola lingkungan Desa.

\section{Pembuatan Alat Pembakaran Sampah}

Setelah dilakukan peninjauan langsung ke beberapa titik lokasi di desa sade ng,masih banyak warga desa yang tidak memperdulikan terkait masalah sampah ada yang membiarkan sampah di biarka berserakan begitu saja ada juga yang membakarnya di tempat yang sangat dekat dengan bangunan rumah yang pastinya akan sangat berpotensi untuk terjadi kebakaran.

Berawal dari hasil observasi tersebut kami memiliki rencana untuk membuat alat pembakaran sampah yang terbuah dari bahan tong besi bekas dengan tujuan saat warga membakar sampah api hasil dari pembakaran tidak membahayakan rumah warga agar terhindar dari bahaya keubakaran.

Alasan dan Tujuan

a) Kurangnya pemahaman masyarakat terhadap proses pengelolaan sampah di Desa Sadeng.

b) Masyarakat kerap membakar sampah hasil rumah tangga dilingkungan sekitar rumah sehingga dapat membahayakan dari segi kesehatan dan memungkinkan hal yang tidak diinginkan (kebakaran).

c) Upaya untuk membantu didalam pelaksanaan program Kampung Ramah Lingkungan terkait pengelolaan sampah di Desa Sadeng

d) Mengurangi bahaya kebakaran dari pembakaran sampah yang tidak sesuai standar.

\section{Pengecetan ulang Madrasah Diniyah}

Mahasiswa dari kelompok KKN Desa Sadeng bersama pengurus madrasah melakukan revitalisasi diantaranya melakukan pengecatan ulang pada dinding yang sudah mulai pudar dan juga melakukan perbaikan pada dinding yang sudah rusak karna termakan usia.

Pengecatan dilakukan dengan tujuan untuk meningkatkan motivasi siswa-siswi madrasah dalam menimba ilmu juga agar terciptanya suasana yang nyaman saat proses belajar berlangsung.

Alasan dan Tujuan

a) Warna cat dasar pada bangunan Madrasah yang sudah mulai pudar karena pengecatan bangunan dilakukan sebelumnya sudah terlalu lama. 
b) Terdapat kerusakan pada dindingdinding Madrasah dan juga instalasi listrik yang kurang sesuai dengan Peraturan Umum Ilmu Listrik (PUIL).

c) Sebagai timbal balik dari mahasiswa kepada masyarakat Desa Sadeng dalam bidang teknik.

Berangkat dari fakta tersebut, Mahasiswa dari kelompok KKN Desa Sadeng bersama pengurus madrasah melakukan revitalisasi dengan melakukan pengecatan ulang pada dinding yg warnanya sudah mulai pudar dan memperbaiki dinding yang sudah rusak karna termakan usia.

\section{Divisi Umum}

\section{Minggu Bersih}

Program ini disusun untuk lebih menumbuhkan sikap gotong royong dan peduli terhadap kebersihan lingkungan kepada para masyarakat. Kegiatan kerja bakti yang telah dilaksanakan menghasilkan lingkungan yang bersih, nyaman, dan lingkungannya terlihat rapi dan terasa nyaman. Lingkungan yang bersih tentu akan membuat kesehatan warga menjadi lebih terjaga karena bersihnya lingkungan dari sampah yang dapat menimbulkan berbagai penyakit.

Program kerja bakti ini dilaksanakan setiap minggu. Minggu pertama dilaksanakan di RW. 01 dan 02, minggu

\section{PENUTUP}

\section{Kesimpulan}

Kuliah Kerja Nyata (KKN) merupakan wadah bagi mahasiswa untuk belajar dan memahami karakteristik kehidupan dimasyarakat, sehingga mahasiswa dapat berperan dan berpartisipasi aktif dalam masyarakat. Secara umum, seluruh rangkaian program kegiatan KKN yang dilaksanakan mulai tanggal 06 Agustus 2019 sampai dengan kedua dilaksanakan di RW. 03 dan 04, dan minggu ketiga di RW. 06 dengan bekerjasama dengan KRL Darussalam.

Alasan dan Tujuan

a) Meningkatkan kualitas kebersihan lingkungan sekitar Desa Sadeng.

b) Meningkatkan kesadaran masyarakat terhadap pentingnya menjaga kebersihan lingkungan secara berkala dan berkelanjutan.

c) Sebagai timbal balik dari mahasiswa kepada desa dalam bidang kebersihan dan kesehatan.

\section{Panitia peringatan hari kemerdekaan Republik Indonesia}

Perlombaan yang kami adakan yaitu untuk anak-anak SD dan Ibu-Ibu, perlombaan yang kami adakan untuk anakanak diantaranya: lomba balap karung, lomba makan kerupuk, lomba memasukan pensil kedalam botol, lomba kelereng, lomba menendang bola, dan lomba untuk ibu-ibu diantaranya: lomba tarik tambang, lomba balap karung, lomba makan kerupuk, lomba maen bola.

Alasan dan Tujuan

a) Memeriahkan perayaan hari kemerdekaan dan Idul Adha di Desa Sadeng.

b) Timbal balik mahasiswa kepada masyarakat Desa Sadeng.

05 September 2019 di Desa Sadeng, Kec. Leuwisadeng Kab. Bogor telah terlaksana dengan baik.

Berdasarkan hasil kegiatan, pengamatan, maupun pelaksanaan program kerja KKN yang telah direncanakan, disusun dan dilaksanakan. Maka kelompok 27 \& 28 KKN Universitas Ibn Khaldun Bogor 2019 di Desa Sadeng Kecamatan 
Leuwiliang mengambil beberapa kesimpulan yaitu :

1. Dengan telah dilaksanakan kegiatan penyuluhan kepada Masyarakat tentang Bank Sampah ternyata terdapat sampah yang bernilai ekonomis untuk meningkatkan kesejahteraan keluarga Desa Sadeng.

2. Potensi desa di Desa Sadeng telah dikelola cukup baik oleh masyarakat, sehingga tercapai hasil yang cukup memuaskan, diantaranya: a) Kerjasama yang baik antara masyarakat, perangkat desa serta instansi terkait guna memperlancar pembangunan desa, b) Kerjasama yang baik dari masyarakat dan mahasiswa didalam pelaksanaan program KRL membantu intensitas dari kegiatan KRL yang sebelumnya tersendat, d) Pemberdayaan swadaya

\section{DAFTAR PUSTAKA}

Bkgc.bogorkab.go.id

\section{http://kompasiana.com}

Administrasi Desa Sadeng, Kec. Leuwsadeng, Kab. Bogor (2019).

Ikhsan, MZ., Prasetya, EP. (2020). Sosialisasi Pendidikan Stop Aksi Bullying. PKM-P, 4 (1).

Ikhtiono, Gunawan., dkk. (2019). "Membangun desa religius dan bersih dari sampah", Jurnal KKN UIKA Vol. 03 No. 1. masyarakat untuk menunjang pembangunan desa.

3. Keberhasilan $\mathrm{KKN}$ tidak lepas dari kerja sama antara mahasiswa dengan perangkat desa, masyarakat, serta semua pihak yang membantu dan mendukung terlaksananya kegiatan KKN tanpa adanya kerja sama yang baik, program kerja KKN tidak akan berjalan dengan lancar.

Dengan demikian, hasil kesimpulan di atas menunjukan bahwa secara garis besar program KKN yang dilaksanakan oleh kelompok 27 \& 28 UIKA dapat dikatakan sukses dan berjalan lancar.

\section{Saran}

Untuk program bank sampah sebaiknya mengadakan pelatihan kerajinan tangan untuk memanfaatkan sampah yang dapat di daur ulang, sehingga sampah dapat bernilai jual tinggi.

Irfani, Fahmi., dkk (2019). "Pengembangan daya tarik wisata bakukung cianten melalui perancangan petunjuk arah berbasis media online". Jurnal UIKA Vol. 03 No. 1

Prasetya, E. (2018). Pemberdayaan Masyarakat Tentang Kesehatan, Pendidikan dan Kreatifitas. Abdi Dosen: Jurnal Pengabdian Pada Masyarakat 2 (1), 19-25. 